\title{
PINK1/BRPK inhibits apoptotic cell death and enahances cellular invasiveness through an activation of mTORC2 pathway
}

\author{
Hitoshi Murata, Masakiyo Sakaguchi, Ken Kataoka, Nam-ho Huh* \\ From 16th International Charles Heidelberger Symposium on Cancer Research \\ Coimbra, Portugal. 26-28 September 2010
}

The PINK1/BRPK gene encodes a serine/threonine kinase with a mitochondrial localization signal. Mutations in the gene is causatively linked to an autosomal recessive form of Parkinson's disease (PD). We showed that PINK1/BRPK was expressed at a higher level in cancer cell lines with higher metastatic potential. When overexpressed, PINK1/BRPK blocked apoptotic cell death of cancer cells induced by various agents, including oxidative stress. Overexpression of wild-type PINK1/ BRPK induced phosphorylation of Akt, an important anti-apoptotic protein. PINK1/BRPK protein is mostly localized in the mitochondria, but the protein is also detected in the cytoplasm and co-precipitated with Akt. Application of an Akt inhibitor abrogated the antiapoptotic effect of PINK1/BRPK. Blocking the EGF receptor-PI3 kinase pathway, an authentic upstream pathway for Akt activation, did not affect phosphorylation of Akt by PINK1/BRPK, indicating that PINK1/ BRPK activates Akt through a mechanism independent from the receptor-PI3 kinase pathway.

Another known upstream effector for Akt is mTORC2. We therefore examined mTORC2 in SHSY5Y cells with overexpression of PINK1. PINK1/BRPK was co-precipitated with components of mTORC2 but not with a component of mTORC1. Prolonged treatment with rapamycin that is known to inhibit mTORC2 cancelled the effect of PINK1/BRPK, while brief treatment with rapamycin that is specific to mTORC1 showed no effect. Furthermore, overexpression of PINK1/BRPK enhanced cellular invasiveness in vitro. These results indicate that mTORC2 is a critical

\footnotetext{
* Correspondence: namu@md.okayama-u.ac.jp Department of Cell Biology, Okayama University Graduate School of Medicine, Dentistry and Pharmaceutical Sciences, Okayama, Japan Full list of author information is available at the end of the article
}

molecule to mediate the anti-apoptotic and prometastatic activity of PINK1/BRPK.

Published: 24 September 2010

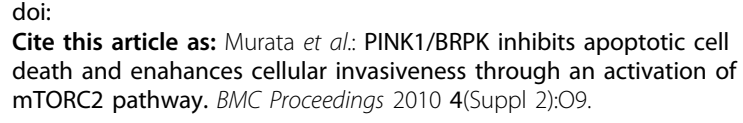

Cite this article as: Murata et al: PINK1/BRPK inhibits apoptotic cell death and enahances cellular invasiveness through an activation of mTORC2 pathway. BMC Proceedings 2010 4(Suppl 2):09.

Submit your next manuscript to BioMed Central and take full advantage of:

- Convenient online submission

- Thorough peer review

- No space constraints or color figure charges

- Immediate publication on acceptance

- Inclusion in PubMed, CAS, Scopus and Google Scholar

- Research which is freely available for redistribution

Submit your manuscript at www.biomedcentral.com/submit
C Biomed Central 